\title{
MEMAHAMI PERAN DAN FUNGSI PERKEMBANGAN PESERTA DIDIK SEBAGAI UPAYA IMPLEMENTASI NILAI PENDIDIKAN KARAKTER DALAM KURIKULUM
}

\author{
Heri Cahyono \\ Universitas Muhammadiyah Metro \\ Jl. Ki Hajar Dewantara No.166 Kota Metro Lampung 34111 \\ hericahyono808@gmail.com \\ Iswati \\ Universitas Muhammadiyah Metro \\ Jl. Ki Hajar Dewantara No.166 Kota Metro Lampung 34111 \\ Iswatiummetro@yahoo.com
}

\begin{abstract}
The students need to plant good characters because the planting of characters must start early, because it will be easier to form. The existing character values of 18 points must absolutely be implemented in each subject and by the level of educational unit. Implementation is by integrating into learning activities with approaches that make learners as their subject. To see the success of this character education implementation, it is necessary to have a good assessment in every subject, class or school in general and the teacher is the leader in value-based learning activities of the nation character, to support the optimization of teacher's role in the integration of character values in learning activities, teachers should have an insight into the knowledge and experience of the values contained in the nation's character broadly and adequately.
\end{abstract}

Keywords: Development of the Students, Character Values, Education Curriculum

\begin{abstract}
Abstrak
Peserta didik membutuhkan penanaman karakter-karakter yang baik karena penanaman karakter harus dimulai sejak dini, karena akan lebih mudah membentuknya. Nilai-nilai karakter yang ada 18 poin mutlak harus dilaksanakan dalam setiap mata pelajaran dan oleh tingkat satuan pendidikan. Pelaksanaanya adalah dengan cara mengintegrasikan ke dalam kegiatan pembelajaran dengan pendekatan yang menjadikan peserta didik sebagai subjeknya. Untuk melihat keberhasilan dari pelaksanaan pendidikan karakter ini perlu dilakukan penilaian baik di setiap mata pelajaran, kelas atau sekolah pada umumnya dan guru merupakan pihak terdepan dalam kegiatan pembelajaran berbasis nilai karakter bangsa, untuk mendukung optimalisasi peran guru dalam integrasi nilai-nilai karakter dalam kegiatan pembelajaran, guru hendaknya memiliki wawasan pengetahuan dan pengalaman tentang nilai-nilai yang terkandung dalam karakter bangsa secara luas dan memadai.
\end{abstract}

Kata Kunci: Perkembangan Peserta Didik, Nilai Karakter, Kurikulum Pendidikan 


\section{Pendahuluan}

Pendidikan adalah usaha sadar yang dilakukan oleh keluarga, masyarakat dan pemerintah melalui kegiatan bimbingan, pengajaran, dan latihan yang berlangsung di sekolah dan di luar sekolah sepanjang hayat, untuk mempersiapkan peserta didik agar dapat memainkan peranan dalam berbagai lingkungan hidup secara tepat di masa yang akan datang. Pendidikan adalah pengalaman-pengalaman belajar terprogram dalam bentuk pendidikan formal, non formal, serta informal di sekolah, dan di luar sekolah, yang berlangsung seumur hidup yang bertujuan optimalisasi pertimbanagan kemampuan-kemampuan individu, agar di kemudian hari dapat memainkan peranan hidup secara tepat. ${ }^{1}$ Pendidikan juga harus mampu menjadi sarana untuk membekali kemampuan problem solving bagi peserta didi. ${ }^{2}$

Pendidikan pula memiliki peran strategis sebagai sarana human resources dan human investment. Selain bertujuan menumbuh kembangkan kehidupan yang lebih baik pendidikan juga telah nyata ikut mewarnai dan menjadi cikal landasan moral dan dan etik dalam proses pemberdayaan jati diri bangsa. Rumusan tujuan pendidikan nasional sebagaimana tertuang dalam Undang-Undang No. 20 Tahun 2003 tentang Sistem Pendidikan Nasional (SISDIKNAS) bertujuan untuk mengembangkan potensi peserta didik agar menjadi manusia yang beriman dan bertakwa kepada Tuhan Yang Maha Esa, berakhlak mulia, sehat, berilmu, cakap, kreatif, mandiri, dan menjadi warga

1 Redja Mudiyaharjo, Pengantar Pendidikan: Sebuah Studi Awal Tentang Dasar-dasar Penddidikan pada Umumnya dan Pendididkan di Indonesia (Jakarta: PT Raja Grafindo Persada, 2002), 11.

2 Abdul Mujib dan Ahmad Madkur, "Islamicbased Life Skill Education on State Vocational High School in Metro City" (Proceeding the First International Conference on Law, Economics and Education, Universitas Muhammadiyah Metro, 2016), 132. negara yang demokratis serta bertanggung jawab. ${ }^{3}$

Berdasarkan tujuan pendidikan nasional tersebut menunjukkan bahwa pada dasarnya terbentuknya nilai karakter menjadi tujuan utama pendidikan nasional, dengan tujuan tersebut diharapkan dalam segala tindakan dan aktivitas dalam pendidikan mengarah pada pengembangan karakter peserta didik.

Dikarenakan pendidikan merupakan bimbingan terhadap perkembangan manusia menuju ke arah cita-cita tertentu, maka yang merupakan masalah pokok bagi pendidikan adalah memilih arah atau tujuan yang akan dicapai dan memilih pembimbing atau pendidik yang tepat sehingga tidak akan mengalami kegagalan.

Lingkungan pertama yang punya peran mendidik anak adalah lingkungan keluarga, disinilah anak dilahirkan, di rawat dan dibesarkan. Disinilah proses pendidikan berawal, orang tua adalah guru pertama dan utama bagi anak. Orang tua adalah guru agama, bahasa dan sosial pertama bagi anak. Orang tua adalah orang yang pertama kali mengajarkan anak berbahasa dengan mengajari anak mengucapkan kata-kata dan mengajarkan anak bersosial dengan lingkungan sekitarnya.

Namun tidak semua tugas mendidik dapat dilaksanakan oleh orang tua dalam keluarga terutama dalam hal ilmu pengetahuan dan berbagai macam disiplin ilmu pengetahuan. Oleh karena itu dikirimlah anak ke sekolah. Dengan demikian, sebenarnya pendidikan di sekolah adalah bagian dari pendidikan dalam keluarga yang sekaligus merupakan lanjutan dari pendidikan keluarga. Dengan masuknya anak ke sekolah, maka terbentuklah hubungan antara rumah dan

Departemen Pendidikan Nasional RI, UU RI No. 20 tahun 2003 tentang Sistem Pendidikan Nasional (Sisdiknas) (Jakarta: Sinar Grafika, 2003), 5. 
sekolah karena antara kedua lingkungan itu terdapat objek dan tujuan yang sama, yakni mendidik anak-anak. ${ }^{4}$

Kompleksitas permasalahan seputar karakter atau moralitas telah menjadi pemikiran sekaligus keprihatinan bersama. Krisis karakter atau moralitas ditandai oleh meningkatnya kejahatan tindak kekerasan, penyalahgunaan obat terlarang (narkoba), pornografi dan pornoaksi serta pergaulan bebas yang sudah menjadi patologi dalam masyarakat.

Menurut M. Masri Muadz, Direktur Remaja dan Perlindungan Hak-Hak Reproduksi Badan Koordinasi Keluarga Berencana Nasional Pusat (BKKBN) menyampaikan bahwa "Hasil survei terakhir suatu lembaga survey yang dilakukan di 33 provinsi tahun 2008, sebanyak 63 persen remajamengakusudahmengalamihubungan seks sebelum nikah, sedangkan data Departemen Kesehatan hingga September 2008, dari 15.210 penderita AIDS atau orang yang hidup dengan HIV/AIDS di Indonesia, 54 persen di antaranya adalah remaja." ${ }^{5}$

Kapolda Metro Jaya, Irjen Putut Eko Bayuseno mengatakan kenakalan remaja, mengalami peningkatan yang cukup tinggi. Pada tahun 2011 tercatat ada 30 kasus, sementara tahun 2012 terjadi 41 kasus. Artinya naik sebanyak 11 kasus, atau meningkat 36,66 persen, sedangkan kasus Narkotika juga mengalami peningkatan, dari 4.817 kasus di 2011 menjadi 4.836 kasus pada 2012. Naik sebanyak 19 kasus atau 0,39 persen. ${ }^{6}$

${ }^{4}$ Zakiah Daradjat, dkk, Ilmu Pendidikan Islam (Jakarta: Bumi Aksara, 1992), 76.

${ }^{5}$ Arista Rosady F. Aning Tias, Hubungan antara Lingkungan Pergaulan dengan Sikap dan Perilaku Seks Bebas Remaja di SMK Murni 2 Surakarta (Surakata: Universitas Muhammadiyah Surakarta, 2015), 1.

${ }^{6}$ Fadhilah Ramadhani dan Duta Nurdibyanandaru, "Pengaruh Self-Compassion terhadap Kompetensi Emosi Remaja Akhir," Jurnal Psikologi Klinis dan Kesehatan Mental 3, no. 3 (2014): 121.
Demoralisasi ini disokong salah satunya oleh proses pembelajaran yang cenderung mengajarkan pendidikan moral dan budi pekerti sebatas tekstual semata dan kurang mempersiapkan pembelajar untuk menyikapi kehidupan yang kontradiktif tersebut. ${ }^{7}$ Jika realitas di lapangan seperti itu, artinya tujuan pendidikan nasional belum tercapai. Tujuan pendidikan dalam Islam sebagaimana disebutkan oleh Imam Al-Ghazali bahwa tujuan pendidikan Islam yang paling utama ialah beribadah dan taqarrub kepada Allah, dan kesempurnaan insani yang tujuannya kebahagiaan dunia akhirat. ${ }^{8}$ Sedangkan menurut Prof. Naquib Al Attas sebagaimana dikutip oleh Adian Husaini bahwa tujuan pendidikan Islam untuk menghasilkan orang yang baik (to produce a good man). ${ }^{9}$

Dalam pandangan Islam, manusia yang baik dan beradab adalah manusia yang kenal akan Tuhannya, tahu akan dirinya, menjadikan Nabi Muhammad SAW sebagai uswah hasanah, mengikuti jalan pewaris Nabi (ulama), dan berbagai kriteria manusia beradab lainnya. Manusia beradab juga harus memahami potensi dirinya dan bisa mengembangkan potensinya, sebab potensi itu adalah amanah dari Allah SWT. ${ }^{10}$ Hal tersebut senada bahwa pada hakekatnya pendidikan adalah upaya dan proses "memanusiakan manusia", pernyataan ini mengandung implikasi bahwa tanpa pendidikan maka manusia tidak menjadi manusia dalam arti yang sebenarnya, yaitu manusia yang utuh dengan segala fungsinya, baik secara fisik maupun psikis. Dalam konteks ini pendidikan merupakan usaha

7 Zubaedi, Desain Pendidikan Karakter: Konsepsi dan Aplikasinya dalam Lembaga Pendidikan (Jakarta: Kencana, 2011), 5 .

8 Ramayulis, Ilmu Pendidikan Islam (Jakarta: Kalam Mulia, 2004), 71-72.

9 Adian Husaini, Pendidikan islam: Membentuk Manusia Berkarakter dan Beradab (Jakarta: Cakrawala Publishing, 2008), 6.

${ }^{10}$ Husaini, 6. 
manusia dalam rangka mewujudkan sifatsifat kemanusiaannya. ${ }^{11}$

Dari paparan di atas bisa dipahami bahwa sesungguhnya hakikat pendidikan itu adalah merubah karakter buruk yang ada dalam diri manusia mejadi baik dan membuat lebih baik lagi karakter yag baik yang ada dalam diri manusia. Tentu hal ini tidak semudah membalikkan kedua telapak tangan karena diperlukan komunikasi dan kerjasama yang aktif dari orang tua, guru/ sekolah dan lingkungan.

Menangani persoalan-persoalan tersebut, maka implementasi pendidikan karakter menjadi suatu keniscayaan. Kemendiknas pada tahun 2010 meluncurkan tambahan kurikulum Pendidikan Karakter dalam kurikulum. Hal ini dilakukan karena karakter bangsa Indonesia belum muncul dalam keseharian. Sehingga, yang menjadi pilot projectnya adalah bidang pendidikan. Hal ini dikarenakan, karakter itu terbentuk dari perubahan paradigma dan paradigma itu dimulai dari lingkungan sekola. ${ }^{12}$

\section{Metode Pengumpulan Data}

Melihat makna yang tersirat dari judul dan permasalahan yang dikaji, penelitian ini adalah termasuk jenis penelitian pustaka denganpendekatankualitatif,yaitu penelitian yang tidak mengadakan perhitungan data secara kuantitatif. ${ }^{13}$ Ada beberapa kunci utama dalam penelitian literature (pustaka) dengan pendekatan kualitatif, yaitu: (a)The researcher is the main instrument that will read the literature accurately; (b) The research is done descriptively. It means describing in the form of words and picture not in the form of number;

${ }^{11}$ Mampuniarti, "Perspektif Humanis Religius dalam Perspektif Inklusif," Jurnal Pendidikan Khusus III, no. 2 (November 2010): 18.

12 Akla, "Desain Pembelajaran Bahasa Arab berbasis Penanaman Karakter untuk Anak Usia Dini," Elementary: Jurnal Ilmiah Pendidikan Dasar 3, no. 2 (2017): 144.

${ }^{13}$ Lexy J Moleong, Metode Penelitian Kualitatif (Bandung: Remaja Rosdakarya, 1990), 2. (c) More emphasized on the process not on the result because the literature is a work that rich of interpretation; (d) The analysis is inductive;(e) The meaning is the main point.

Literatur utama atau primer yang di kaji dalam penelitian ini adalah buku dan literature pendidikan karakter dan psikologi perkembangan. Sebagai penelitian kepustakaan, maka metode pengumpulan data yang dipergunakan adalah metode dokumentasi, yaitu data tentang variabel yang berupa buku, catatan, transkrip, surat kabar, majalah, jurnal dan lain-lain. Sedangkan teknik analisis yang dipilih adalah deskriptif analisis.

\section{Pembahasan}

\section{A. Perkembangan Peserta Didik}

Pada setiap perkembangan kehidupan manusia, individu itu ditutntut untuk menguasai kemampuan beperilaku yang menjadiciri bahwa perkembangannya berhasil dan normal. Dari waktu ke waktu kehidupan manusia terus berubah. Berawal dari dua sel dasar yaitu sel telur dan sperma, suatu organisme tumbuh dan berkembang. Dua sel tersebut kemudian membelah diri dan berdiferensiasi untuk menghasilkan tulang-tulang, syaraf, otot, usus, otak, dan bagian-bagian organ tubuh lainnya. Setelah kurang lebih sembilan bulan lamanya dalam kandungan ibu, organisme yang baru tumbuh tersebut akhirnya menjadi bayi manusia yang sempurna dan siap lahir ke dunia dengan perangkat keterampilan hidup minimal yaitu bernafas, menggerakgerakkan tubuh, menangis, dan menyusu.

Meskipun di saat lahir hanya berbekal seperangkat keterampilan minimal, melalui interaksi dengan lingkungan (orang tua, saudara, orang dewasa lain, dan objek-objek yang ada di sekitarnya) sang bayi terus lebih menyempurnakan diri. Ia terus mengalami berbagai perubahan atas bimbingan Allah SWT. 
Perkembangan manusia sebagai mahluk sosial tentu tidak dapat lepas dari kehidupan lingkungannya. Hal inilah yang menjadi salah satu dorongan perkembangan psikologis, jasmani, inteligensi pada diri manusia. Sejak manusia dilahirkan ke muka bumi, yang awalnya adalah bersih ( fitrah ) maka lambat laun ia terkontaminasi dengan lingkungannya sesuai dengan peran dan kemampuan panca inderanya.

Dalam perkembangannya secara psikologis mulai dari bayi menjadi anakanak kemudian menjadi remaja dan akhirnya menjadi dewas. ${ }^{14}$ Pada usia remaja inilah banyak sekali muncul problem kehidupan yang dirasakan oleh remaja. Maka tentunya, remaja harus tahu benar-benar peran dan fungsinya sebagai seorang remaja. Di sinilah peran orang tua untuk melakukan bimbingannya dengan sebaik-baiknya pula.

\section{B. Tugas-tugas Perkembangan}

Arti tugas-tugas perkembangan dapat dikelompokkan menjadi $2::^{15}$

a. Tugas-tugas perkembangan adalah petunjuk-petunjuk yang memungkinka seseorang mengerti dan memahami apa yang diharapkan atau dituntut oleh masuarakat dan lingkungan lain terhadap seseorang dalam usia-usia tertentu. Arti pertama ini mengandung makna, pertama; dari segi orang dewasa. Kedua, dari segi yang sadar menuju kedewasaanya.

b. Tugas-tugas perkembangan merupakan petunjuk bagi seorang tentang apa dan bagaimanayang diharapkan daripadanya pada masa yang akan datang, jika dia kelak telah mencapainya. Arti kedua ini mengandung makna, dari segi pendidik

14 Khotijah, "Strategi Pengembangan Bahasa pada Anak Usia Dini," Elementary: Jurnal Ilmiah Pendidikan Dasar 2, no. 2 (2016): 25.

15 Juhri AM, Landasan Wawasan Pendidikan: Suatu Pendekatan Kompetensi Guru, Cet. 4 (Metro: Lembaga Penelitian UM Metro, 2013), 125-26. dan dari segi warga didik ( dalam masa pubertas, remaja).

Tugas-tugas perkembangan manusia dalam tiap masa kehidupannya menurut Havigrust, Karl C Garrison, William W Wattenberg sebagaimana disebutkan oleh Juhri dalam bukunya menekankan pada halhal tugas sebagai berikut :

1. Tugas-tugas Perkembangan dalam Masa Bayi dan Kanak-kanak Awal

a. Belajar berjalan

b. Belajar makan makanan padat

c. Belajar mengendalikan buang air kecil dan besar

d. Memperoleh keseimbangan psikologis

e. Belajar membedakan jenis kelamin dan menghargainya

f. Menyusun konsep sederhana tentang realitas sosial dan realitas fisik

g. Belajar menjalin hubungan secara emosional antara dirinya dengan orang tuanya, saudara-sauara dan orang lain

h. Belajar mengembangkan peran hati nurani dalam membedakan "benar salah".

2. Tugas-tugas Perkembangan Masa Kanakkanak Akhir

Belajar tentang keterampilan fisik yang diperlukan dalam permainan yang ringan-ringan atau mudah.

a. Membentuk sikap-sikap sehat terhadap dirinya demi kepentingan organismenya yang sedang tumbuh

b. Belajar untuk bergaul dan bermain bersama dengan teman seusia

c. Belajar menyesuaikan diri dengan keadaaan dirinya sebagai wanita atau pria

d. Mengembangkan keterampilanketerampilan dsar dalam membaca, menulis dan berhitung

e. Mengembangkan konsep-konsep yang diperlukan dalam kehidupan sehari-hari 
f. Mengembangka kata hari, moral dan ukuran nilai-nilai

g. Mengembangkan sikap-sikap dalam memandang kelompok-kelompok sosial dan lembaga masyarakat.

3. Tugas-tugas Perkembangan dalam Masa Remaja

a. Menerima keadaan fisikya dan menerima peranannya sebagai pria atau wanita

b. Menjalin hubungan-hubungan baru dengan teman-teman sebaya baik sesama jenis maupun lain jenis kelamin

c. Memperoleh kebebasan secara emosional dari orang tuanya dan orang-orang dewasa lain

d. Memperoleh kepastian dalam hal kebebasan pengaturan ekonomis

e. Memilih dan mempersiapkan diri ke arah suatu pekerjaan atau jabatan

f. Mengembangkan keterampilanketerampilan dan konsep-konsep intelektual yang diperlukan dalam hidup sebagai warga negara yang terpuji

g. Menginginkan dan dapat berperilaku yang diperbolehkan oleh masyarakat

h. Mempersiapkan diri untuk pernikahan dan hidup keluarga

i. Menyusun nilai-nilai kata hati yang sesuai dengan gambaran dunia.

4. Tugas-tugas Perkembangan dalam Masa Dewasa Awal
a. Memilih teman bergaul
b. Belajar hidup bersama dengan suami atau istri
c. Mulai hidup dalam keluarga
d. Belajar mengasuh anak-anak
e. Mengelola rumah tangga
f. Mulai bekerja dalam suatu jabatan
g. Mulai bertanggungjawab sebagai warga negara secara layak
h. Memperoleh kelompok sosial seirama dengan nilai-nilai pahamnya

5. Tugas-tugas Perkembangan dalam masa Setengah Baya
a. Memperolehtanggungjawabsebagai orang dewasa
b. Menetapkan dan memelihara suatu standar kehidupan
c. Membantu anak-anak remajanya untuk menjadi orang dewasa
d. Menetapkan dan memelihara suatu standar kehidupan ekonomi bagi kehidupannya
e. Mengembangkan kegiatan-kegiatan pengisi waktu senggang yang sesuai dengan orang dewasa

6. Tugas-tugas Perkembangan dalam masa Tua

a. Menyesuaikan diri pada keadaan berkurangnya kekuatan fisik dan kesehatan

b. Menyesuaikan diri dalam msa pensiun dan pendapatan yang berkurang

c. Menyesuaikan diri dalam keadaan meninggalnya suami atau istri

d. Memenuhi kewajiban-kewajiban sebaga warga negara dan kewajiban dalam hidup bermasyarakat

e. Menyusun keadaan hidup yang memuaskan dalam hal fisik.

\section{Tugas-tugas Perkembangan Remaja pada Umumnya}

Tugas-tugas perkembangan remaja pada umumnya, yang secara teknis berbeda pengelompokannya dengan rumusan tersebut di atas. Menurut Karl C Garrison membagi tugas-tugas perkembangan dalam enam kelompok, yaitu ${ }^{16}$ :

1. Menerima Keadaan Jasmani

2. Memperoleh Hubungan Baru dan Lebih Matang dengan Teman-teman Sebaya Antara Dua Jenis Kelamin

3. Menerima Keadaan Sesuai Jenis

16 Muhammad Al Mighwar, Psikologi Remaja: Petunjuk bagi Guru dan Orang Tua (Bandung: Pustaka Setia, 2006), 87. 
Kelaminnya dan Belajar Hidupa Seperti Kaumnya

4. Memperoleh kebebasan Emosional dari Orang Tua dan Orang Dewasa Lainnya

5. Memperoleh Kesanggupan Berdiri Sendiri dalam Hal-hal yang Bersangkutan dengan Ekonomi/Keuangan

6. Mendapatkan Perangkat Nilai-nilai Hidup dan Falsafah Hidup.

Tugas-tugas Perkembangan Remaja Awal sebagai berikut :

7. Memiliki kemampuan Mengontrol diri sendiri seperti orang dewasa

8. Memperoleh kebebasan

9. Bergaul dengan teman lawan jenis

10. Mengembangkan keterampilan

11. Memiliki citra diri yang realistis

Pelaksanaan

Tugas-tugas

Perkembangan Remaja bersangkutan erat dengan :

a. Pentingnya Kelancaran Pelaksanaan tugas-tugas Pekembangan; yang meliputi : kematangan fisik, tekanan-tekanan, nilai-nilai dan kemauan-kemauan pribadi seseorang

b. Faktor-faktor yang mempengaruhi kelancaran pelaksanaan tugas-tugas perkembangan, diantaranya :

- Pertumbuhan fisik remaja

- Perkembangan psikis remaja

- Kedudukan/urutan anak dalam keluarga

- Kesempatan bagi remaja untuk mempelajari tugas-tugas perkembangan

- Motivasi pada seseorang

- Kelancaran pelaksanaan tugas-tugas perkembangan masa sebelumnya.

c. Beberapa variasi dalam pelaksanaan tugas-tugas perkembangan, dapat meliputi :

- Variasi yang berkenaan dengan tugas perkembangan itu sendiri

- Variasi yang berkenaan dengan individu pelaksanaan itu sendiri

- Variasi yang terjadi dan bersangkutan dengan rentangan periode kehidupan remaja

- Variasi yang bersangkutan dengan situasi dan kondisi sesaat yang terjadi.

\section{Pendidikan Karakter}

\section{Urgensi Pendidikan Karakter}

Karena terjadi perubahan aspek fisik dan psikologis pada manusia, maka tentunya terjadi pula perubahan peranperan perkembangan. Pada masa-masa perkembangan itulah terjadi pembentukan karakter yang dimulai sejak usia anak-anak, bahkan ada yang berpendapat pendidikan karakter atau membentuk karakter anak itu dimulai sejak pra konsepsi dan pre natal.

Pemerintah Indonesia, melalui Kementerian Pendidikan Nasional sudah mencanangkan penerapan pendidikan karakter untuk semua tingkat pendidikan, dari SD-Perguruan Tinggi. Menurut Mendiknas masa Prof. Muhammad Nuh, pembentukan karakter perlu dilakukan sejak usia dini. Jika karakter sudah terbentuk sejak usia dini, kata Mendiknas, maka tidak akan mudah untuk mengubah karakter seseorang. Ia juga berharap, pendidikan karakter dapat membangun kepribadian bangsa. Mendiknas mengungkapkan hal ini saat berbicara pada pertemuan Pimpinan Pascasarjana LPTK Lembaga Pendidikan Tenaga Kependidikan (LPTK) se-Indonesia di Auditorium Universitas Negeri Medan (Unimed), Sabtu (15/4/2010).

Banyak pakar bidang moral dan agama yang sehari-hari mengajar tentang kebaikan, tetapi perilakunya tidak sejalan dengan ilmu yang diajarkannya. Sejak kecil, anakanak diajarkan menghafal tentang bagusnya sikap jujur, berani, kerja keras, kebersihan, dan jahatnya kecurangan. Tapi, nilai-nilai kebaikan itu diajarkan dan diujikan sebatas pengetahuan di atas kertas dan dihafal sebagai bahan yang wajib dipelajari, karena diduga akan keluar dalam kertas soal ujian. 
Praktik-praktik tidak terpuji terus berlangsung dengan kasat mata di tengah masyarakat. Tak terkecuali di dunia pendidikan. Ujian Nasional dijadikan ajang kepentingan politik untuk meluluskan semua peserta didik dengan berbagai cara yang penting pemerintah senang, Asal Bapak Senang (ABS). Dimulakan dengan memberikan kunci jawaban, memberikan contekan, membolehkan antar peserta contekan, sampai kepada settingan cara memberikan contekan. Padahal, di kelas digembor-gemborkan untuk bersikap jujur, tetapi saat Ujian Nasional semuanya dilupakan. Rasa muroqobatullah sama sekali tidak muncul dalam diri peserta didik dan para pendidik. Nilai seorang pendidik telah hancur.

Pendidikan karakter bukanlah sebuah proses menghafal materi soal ujian, dan teknik-teknik menjawabnya. ${ }^{17}$ Pendidikan karakter memerlukan pembiasaan. Pembiasaan untuk berbuat baik; pembiasaan untuk berlaku jujur, ksatria; malu berbuat curang; malu bersikap malas; malu membiarkan lingkungannya kotor. Karakter tidak terbentuk secara instan, tapi harus dilatih secara serius dan proporsional agar mencapai bentuk dan kekuatan yang ideal.

Menurut Adian Husaini, bahwa karakter memang laksana "otot" yang memerlukan latihan demi latihan untuk menjaga dan meningkatkan kualitas kesehatan dan kekuatannya. Karena itu, pendidikan karakter memerlukan proses pemahaman, penanaman nilai, dan pembiasaan, sehingga seorang anak didik mencintai perbuatan baik. Contoh, untuk mendidik agar anak mencintai kebersihan, maka harus dilakukan pembiasaan hidup bersihdandiberikanpemahamanagarmereka mencintai kebersihan. Tentu, ini adalah cara yang baik dan memerlukan kesabaran

17 Hamdi A. Karim, "Pendidikan Karakter di Madrasah Ibtidaiyah," Elementary: Jurnal Ilmiah Pendidikan Dasar 2, no. 2 (2016): 46. dalam pendidikan. ${ }^{18}$ Di sinilah bisa kita pahami, mengapa ada kesenjangan antara praktik pendidikan dengan karakter peserta didik. Bisa dikatakan, dunia Pendidikan di Indonesia kini sedang memasuki masamasa yang sangat pelik. Kucuran anggaran pendidikan yang sangat besar disertai berbagaiprogramterobosansepertinyabelum mampu memecahkan persoalan mendasar dalam dunia pendidikan, yakni bagaimana mencetak alumni pendidikan yang unggul, yang beriman, bertaqwa, profesional, dan berkarakter, sebagaimana tujuan pendidikan dalam UU Sistem Pendidikan Nasional.

Secara implisit telah ditegaskan dalam Rencana Pembangunan Jangka Panjang Nasional (RPJPN) tahun 2005-2025, di mana pemerintah menjadikan pembangunan karakter sebagai salah satu program prioritas pembangunan nasional. ${ }^{19}$ Maka dari paparan di atas, tentunya sangat diperlukan sekali sebuah proses pembelajaran yang mengintegrasikan nilai-nilai karakter bangsa dan budaya lokal yang semuanya akan menjadi kekuatan sendiri bagi peserta didik untuk bekal hidup di kehidupannya. Bukan sekedar out put peserta didik yang bernilai kognitif tinggi-tinggi, tetapi out came dari pembelajaran benar-benar terintegrasi dalam diri seorang peserta didik sehingga ia siap bersaing dengan dunia global.

\section{Nilai-nilai Pendidikan Karakter}

Nilai-nilai yang dikembangkan dalam pendidikan budaya dan karakter bangsa diidentifikasi dari sumber-sumber inti. Sumber dimaksud adalah Agama, Pancasila, budaya dan Tujuan Pendidikan Nasional.

Menyadari bahwa bangsa Indonesia adalah bangsa yang beragama, maka nilai

${ }^{18}$ Husaini, Pendidikan islam: Membentuk Manusia Berkarakter dan Beradab, 18.

19 Endah Sulistyowati, Implementasi Kurikulum Pendidikan Karakter (Yogyakarta: PT. Cintra Aji Parama, 2012), 5 . 
yang terkandung dalam agamanya dijadikan dasar membentuk karakter bangsa. Pancasila dijadikan sumber karena dalam kehidupan berbangsa dan bernegara Pancasila adalah dasarnya. Selain itu mengingat bahwa bangsa Indonesia terbentuk dari berbagai macam suku bangsa dan beranekaragam budaya, maka adalah suatu keharusan dalam menanamkan nilai karakter bangsa berdasarkan nilai budaya yang ada di mana merekaberada. Did alamkonteks pendidikan, dengan bersumber dari agama, Pancasila dan budaya maka secara teknis dirumuskan melalui tujuan nasional pendidikan.

Pendidikan karakter yang telah dicanangkan tahun 2010 oleh pemerintah, tentunya memiliki value tersendiri yang telah disusun oleh tim PUSKUR yang merupakan perenungan dalam dari kondisi bangsa Indonesia. Karakter-karakter apa saja yang telah hilang dari budaya dan karakter negeri ini. Adapun nilai-nilai pendidikan karakter yang diintegrasikan dalam pembelajaran secara operasional adalah sebagai berikut :20

Tabel 1. Nilai dan Deskripsi Nilai Pendidikan Karakter

\begin{tabular}{crl}
\hline No & Nilai & \multicolumn{1}{c}{ Deskripsi } \\
\hline 1 & Religius & Sikap dan perilaku \\
& & yang patuh dalam \\
& melaksanakan \\
& & ajaran agama \\
& & yang dianutnya, \\
& & toleran terhadap \\
& pelaksanaan ibadah \\
& agama lain, dan \\
& hidup rukun dengan \\
& pemeluk agama lain. \\
&
\end{tabular}

20 Sri Judiani, “Implementasi Pendidikan Karakter di Sekolah Dasar Melalui Penguatan Pelaksanaan Kurikulum," Jurnal Pendidikan dan Kebudayaan 16, no. III (Oktober 2010): 284.

\begin{tabular}{|c|c|c|}
\hline 2 & Jujur & $\begin{array}{l}\text { Perilaku yang } \\
\text { didasarkan pada } \\
\text { upaya menjadikan } \\
\text { dirinya sebagai } \\
\text { orang yang selalu } \\
\text { dapat dipercaya } \\
\text { dalam perkataan, } \\
\text { tindakan, dan } \\
\text { pekerjaan. }\end{array}$ \\
\hline 3 & Toleransi & $\begin{array}{l}\text { Sikap dan tindakan } \\
\text { yang menghargai } \\
\text { perbedaan agama, } \\
\text { suku, etnis, } \\
\text { pendapat, sikap, dan } \\
\text { tindakan orang lain } \\
\text { yang berbeda dari } \\
\text { dirinya. }\end{array}$ \\
\hline 4 & Disiplin & $\begin{array}{l}\text { Tindakan yang } \\
\text { menunjukkan } \\
\text { perilaku tertib dan } \\
\text { patuh pada berbagai } \\
\text { ketentuan dan } \\
\text { peraturan. }\end{array}$ \\
\hline 5 & Kerja Keras & $\begin{array}{l}\text { Perilaku yang } \\
\text { menunjukkan upaya } \\
\text { sungguh-sungguh } \\
\text { dalam mengatasi } \\
\text { berbagai hambatan } \\
\text { belajar dan tugas, } \\
\text { serta menyelesaikan } \\
\text { tugas dengan } \\
\text { sebaik-baiknya. }\end{array}$ \\
\hline 6 & Kreatif & $\begin{array}{l}\text { Berpikir dan } \\
\text { melakukan sesuatu } \\
\text { untuk menghasilkan } \\
\text { cara atau hasil baru } \\
\text { dari sesuatu yang } \\
\text { telah dimiliki. }\end{array}$ \\
\hline 7 & Mandiri & $\begin{array}{l}\text { Sikap dan perilaku } \\
\text { yang tidak mudah } \\
\text { tergantung pada } \\
\text { orang lain dalam } \\
\text { menyelesaikan } \\
\text { tugas-tugas. }\end{array}$ \\
\hline
\end{tabular}




\begin{tabular}{|c|c|c|}
\hline 8 & Demokratis & $\begin{array}{l}\text { Cara berfikir, } \\
\text { bersikap, dan } \\
\text { bertindak yang } \\
\text { menilai samahak } \\
\text { dan kewajiban } \\
\text { dirinya dan orang } \\
\text { lain. }\end{array}$ \\
\hline 9 & $\begin{array}{l}\text { Rasa Ingin } \\
\text { Tahu }\end{array}$ & $\begin{array}{l}\text { Sikap dan tindakan } \\
\text { yang selalu } \\
\text { berupaya untuk } \\
\text { mengetahui lebih } \\
\text { mendalam dan } \\
\text { meluas dari sesuatu } \\
\text { yang dipelajarinya, } \\
\text { dilihat, dan } \\
\text { didengar. }\end{array}$ \\
\hline 10 & $\begin{array}{l}\text { Semangat } \\
\text { Kebangsaan }\end{array}$ & $\begin{array}{l}\text { Cara berpikir, } \\
\text { bertindak, dan } \\
\text { berwawasan yang } \\
\text { menempatkan } \\
\text { kepentingan bangsa } \\
\text { dan negara di atas } \\
\text { kepentingan diri } \\
\text { dan kelompoknya. }\end{array}$ \\
\hline 11 & $\begin{array}{l}\text { Cinta Tanah } \\
\text { Air }\end{array}$ & $\begin{array}{l}\text { Cara berfikir, } \\
\text { bersikap, dan } \\
\text { berbuat yang } \\
\text { menunjukkan } \\
\text { kesetiaan, } \\
\text { kepedulian, dan } \\
\text { penghargaan yang } \\
\text { tinggi terhadap } \\
\text { bahasa, lingkungan } \\
\text { fisik, sosial, budaya, } \\
\text { ekonomi, dan politik } \\
\text { bangsa. }\end{array}$ \\
\hline 12 & $\begin{array}{l}\text { Menghargai } \\
\text { Prestasi }\end{array}$ & $\begin{array}{l}\text { Sikap dan tindakan } \\
\text { yang mendorong } \\
\text { dirinya untuk } \\
\text { menghasilkan } \\
\text { sesuatu yang } \\
\text { berguna bagi } \\
\text { masyarakat, dan } \\
\text { mengakui, serta } \\
\text { menghormati } \\
\text { keberhasilan orang } \\
\text { lain. }\end{array}$ \\
\hline
\end{tabular}

\begin{tabular}{|c|c|c|}
\hline 13 & $\begin{array}{l}\text { Bersahabat/ } \\
\text { Komuniktif }\end{array}$ & $\begin{array}{l}\text { Tindakan yang } \\
\text { memperlihatkan } \\
\text { rasa senang } \\
\text { berbicara, bergaul, } \\
\text { dan bekerja sama } \\
\text { dengan orang lain. }\end{array}$ \\
\hline 14 & $\begin{array}{l}\text { Cinta } \\
\text { Damai }\end{array}$ & $\begin{array}{l}\text { Sikap, perkataan, } \\
\text { dan tindakan yang } \\
\text { menyebabkan orang } \\
\text { lain merasa senang } \\
\text { dan aman atas } \\
\text { kehadiran dirinya. }\end{array}$ \\
\hline 15 & $\begin{array}{l}\text { Gemar } \\
\text { Membaca }\end{array}$ & $\begin{array}{l}\text { Kebiasaan } \\
\text { menyediakan waktu } \\
\text { untuk membaca } \\
\text { berbagai bacaan } \\
\text { yang memberikan } \\
\text { kebajikan bagi } \\
\text { dirinya. }\end{array}$ \\
\hline 16 & $\begin{array}{l}\text { Peduli } \\
\text { Lingkungan }\end{array}$ & $\begin{array}{l}\text { Sikap dan tindakan } \\
\text { yang selalu } \\
\text { berupaya mencegah } \\
\text { kerusakan pada } \\
\text { lingkungan alam } \\
\text { di sekitarnya, dan } \\
\text { mengembangkan } \\
\text { upaya-upaya untuk } \\
\text { memperbaiki } \\
\text { kerusakan alam } \\
\text { yang sudah terjadi. }\end{array}$ \\
\hline 17 & $\begin{array}{l}\text { Peduli } \\
\text { Sosial }\end{array}$ & $\begin{array}{l}\text { Sikap dan tindakan } \\
\text { yang selalu ingin } \\
\text { memberi bantuan } \\
\text { pada orang lain dan } \\
\text { masyarakat yang } \\
\text { membutuhkan. }\end{array}$ \\
\hline 18 & $\begin{array}{l}\text { Tanggung- } \\
\text { jawab }\end{array}$ & $\begin{array}{l}\text { Sikap dan perilaku } \\
\text { seseorang untuk } \\
\text { melaksanakan tugas } \\
\text { dan kewajibannya, } \\
\text { yang seharusnya } \\
\text { dia lakukan, } \\
\text { terhadap diri } \\
\text { sendiri, masyarakat, } \\
\text { lingkungan (alam, } \\
\text { sosial dan budaya), } \\
\text { negara dan tuhan } \\
\text { yang maha esa. }\end{array}$ \\
\hline
\end{tabular}




\section{Implementasi Pendidikan Karakter}

Pendidikan karakter (Pendikar) yang telah dicanangkan tentunya tidak akan bermanfaat dan menghasilkan outcame yang diharapkan jika tidak diimplementasikan dengan baik.

Menurut Endah Sulistyowati bahwa implementasi pendidikan karakter di sekolah dikembangkan melalui pengalaman belajar dan proses pembelajaran yang bermuara pada pembentukan karakter dalam diri siswa. Pendidikan karakter dalam kegiatan belajar mengajar di kelas, dilaksanakan dgn menggunakan pendekatan terintegrasi dalam semua mata pelajaran. Dengan demikian, pendidikan yang sangat dibutuhkan saat ini adalah pendidikan yang dapat mengintegrasikan pendidikan karakter dengan pembelajaran yang dapat mengintegrasiikan pendidikan karakter dengan pembelajaran sehingga dapat mengoptimalkan perkembangan seluruh dimensi aak, yaitu kognitif, fisik, psikomotorik, sosial,emosi, kreativitas dan spirituad. ${ }^{21}$

Implementasi pendidikan karakter ini, harapannya tidak sampai merepotkan guru sehingga guru sekedar mengejar pembuatan perangkat ajar saja dan berfikir perangkat yang baik tapi aplikasinya sama sekali tidak ada. Yang ideal adalah penyusunan perangkat yang baik dan diiringi dengan pemahaman guru yang baik dan benar pula terhadap karakter-karakter yang akan diimplementasikan sekaligus adanya pemberian contoh yang baik.

\section{Implementasi Nilai Karakter dalam Pembelajaran di Kelas}

Semestinya pendidikan merupakan sebuah persiapan untuk hidup di masa depan melalui kehidupan masa kini. Kebutuhan masa kanak-kanak berbeda dengan kebutuhan masa dewasa. Ketika anak belajar mengatasi permasalahan di

21 Sulistyowati, Implementasi Kurikulum Pendidikan Karakter, 124. masa kini, sesungguhnya secara alami menyiapkan anak-anak untuk hidup di masa dewasa. ${ }^{22}$ Maka pendidikan karakter ini tidak sekedar teoritis saja.

Prinsippenerapan pendidikankarakter yang pertama adalah nilai-nilai karakter tidaklah diajarkan tetapi dikembangkan. Hal ini mengandung makna bahwa materi nilai budaya dan karakterbangsa bukanlah bahan ajar biasa. Sehingga, nilai-nilai itu tidak dijadikan pokok bahasan yang dikemukakan seperti halnya ketika mengajarkan suatu konsep, teori, prosedur, ataupun fakta seperti dalam mata pelajaran agam, bahasa Indonesia, PKn, IPA, IPS, matematika dan lainnya. Untuk mengembangkan nilainilai itu, guru dapat menggunakan materi pelajaran sebagai bahan atau media untuk mengembangkan nilai-nilai budaya dan karakter bangsa. Oleh karena itu, guru tidak perlu mengubah pokok bahasan yang sudah ada, tetapi mengembangkan nilai-nilai budaya dan karakter bangsa. Selain itu, guru tidak harus mengemabngkan proses belajar khusus untuk mengembangkan nilai. ${ }^{23}$

Prinsip kedua dalam menerapkan pendidikan karakter ini adalah proses pendidikan dilakukan siswa secara aktif dan menyenangkan. Prinsipini meyatakan bahwa proses pendidikan nilai budaya dan karakter bangsa dilakukan siswa bukan guru. Guru menerapkan prinsip "Tut Wuri Handayani" dalam setiap prilaku yang ditunjukkan siswa. Prinsip ini juga menunjukkan bahwa prses pendidikan dilakukan dalam suasana belajar yang menyenangkan, bahagia, fun dan tidak diskriminatif.

Agar kedua prinsip di atas dapat dilaksanakan dengan baik di kelas, maka perlu difikirkan pendekatan pembelajaran yang digunakan. Intinya pendidikan karakter

22 Doni Koesuma A, Pendidikan Karakter: Strategi Mendidik Anak di Zaman Global (Jakarta: Grasindo, 2007), 38.

Sulistyowati, Implementasi Kurik - ir .lum Pendidikan Karakter, 126 
ini dilaksanakan dengan pendekatan integrasi dalam semua pelajaran dan saling berhhubungan dengan satu sama lainnya.

\section{Pendekatan Pembelajaran Pendidikan Karakter di Kelas}

Untuk menginternalisasikan nilainilai karakter maka diperlukan pendekatan pembelajaran yang tentunya peserta didik sebagai pelaku subjeknya, sedangkan pendidik/guru berperan sebagai fasilitator.

Pendekatan kontekstual merupakan salah satu pendekatan (approach) dalam proses internalisasi pendidikan karakter ini. Maksud dari pendekatan ini adalah guru mampu mengaitkan materi yang disampaikan dengan situasi dunia nyat. ${ }^{24}$ Sehingga peserta didik mampu untuk membuat hubungan antara pengetahuan yang dimilikinya dengan penerapannya dalam kehidupan mereka.

Dengan demikian peserta didik memiliki hasil yang komprehensif tidak hanya pada tataran kognitif atau teori, tetapi pada tataran affektif dan psikomotorik. Pendekatan ini melibatkan 7 komponen utama pembelajaran produktif, yaitu: contructivism, questioning, inquiry, learning community, modeling, reflection, dan authentic assessment. ${ }^{25}$ Pembelajaran kontekstual mencakup beberapa strategi, yaitu: a. Pembelajaran berbasis masalah (Problem Base Learning), b. Pembelajaran kooperatif (Cooperative Learning), c. Pembelajaran berbasis proyek (Project Base Learning), d. Pembelajaran pelayanan (Service Learning), e. Pembelajaran berbasis kerja (Do Base Learning)

Selain pendekatan kontekstual sebagai seorang pendidik dapat menggunakan pendekatan lain dalam menginternalisasikan

${ }^{24}$ Ahmad Madkur, "ELT in Indonesian Context: Which One is Better? NESTs or NNESTs," Iqra': Jurnal Kajian Ilmu Pendidikan 2, no. 2 (2017): 289.

25 Sulistyowati, Implementasi Kurikulum Pendidikan Karakter, 128. pendidikan karaktker ini dengan fun. Pendekatan Multiple Inteligensi adalah salah satunya. Pendekatan ini digunakan dengan memanfaatkan jenis-jenis kecerdasan peserta didik Adapun strategi dalam pendekatan ini adalah sebagai berikut : Strategi Diskusi, Strategi action research, Strategi klasifikasi, Strategi Analogi, Strategi identifikasi, Strategi Sosiodrama, Strategi Penokohan, Strategi Flash Card, Strategi Gambar Visual, Strategi Papan (Karton) Permainan, Strategi Wayang, Strategi Applied Learning, Strategi Movie Learning, Strategi Environment Learning, Strategi Service Learning. ${ }^{26}$ Agar belajar potensial sehingga dapat mengembangkan karakter siswa harus memenuhi prinsipprinsip atau kriteria yang berorientasi pada tujuan, input, aktivitas, pengaturan, peran guru, peran siswa. ${ }^{27}$

\section{Implementasi Nilai Karakter dalam Kegiatan Pembinaan Siswa}

Salahsatupilaruntukmengembangkan nilai karakter, selain melalui pembelajaran di dalam kelas adalah dengan melaksanakan kegiatan pembinaan yang terbimbing. Dalam Permendiknas No.39 tahun 2008 disebutkan bahwa tujuan kegiatan pembinaan siswa adalahh menyiapkan siswa agar menjadi warga masyarakat yang berakhlak mulia, demokratis, menghormati hak-hak asasi manusia dalam rangka mewujudkan masyarakat madani.

Dari dasar tersebut bisa dimengerti bahwa pembinaan kesiswaan dapat dilakukan di luar pembelajaran di dalam kelas yaitu di luar kelas. Bisa dilakukan dalam ekstrakurikuler sesuai minat, bakat dan potensi yang dimilikinya. Dapat juga dengan melakukan sebuah proyek di masyarakat.

Dalam kegiatan pembinaan ini lebih kepada pembentukan karakter anak

${ }^{26}$ Munif Chatif, Sekolahnya Manusia, II (Jakarta: Kaifa, 2012), 138-88.

${ }^{27}$ Sulistyowati, Implementasi Kurikulum Pendidikan Karakter, 130. 
(characer building ) dengan meminimalisir pengetahuan tetapi lebih kepada praktik dan peserta didik merasakan langsung. Menurut Indra Djati, motto yang dikembangkan dalam pembinaan siswa ini adalah gembira dan rendah hati. Masih menurut Indra Djati bahwa tiga perempat dari kegiatan kesiswaan ini adalah pembentukan karakter, kompetensi, profesionalitas dan patriotisme..$^{28}$

Pembinaan karakter melalui kegiatan kesiswaan tentunya menyesuaikan jenis kegiatan ekstrakurikuler yang merupakan pengejawantahan visi dan misi satuan pendidikan tertentu. Dapat juga dilakukan pengembangan kegiatan kesiswaan dengan menyesuaikan kebutuhan situasi, kondisi dan kebutuhan global maupun daerah.

Bentuk-bentuk kegiatan pembinaan kesiswaan mengarah kepada :

a. Keimanan dan ketaqwaan terhadap Tuhan Yang Maha Esa

b. Budi pekerti luhur atau akhlak mulia

c. Kepribadian unggul, wawasan kebangsaan dan bela negara

d. Prestasi akademik, seni, olahhraga sesuai minat dan bakat

e. Demokrasi, hak asasi manusia, pendidikan politik, lingkungan hidup, kepekaan dan toleransi dalam konteks masyarakat plural

f. Kreativitas, ketrampian dan kewirausahaan

g. Kualitas jasmani, kesehatan dan gizi berbasis sumber gizi yang terdiversifikasi

h. Sastra dan budaya

i. Tekhnologi informasi dan komunikasi

j. Komunikasi dalam bahasa inggris. ${ }^{29}$

Jaringan Sekolah Islam Terpadu Indonesia (JSIT) Indonesia dalam buku Standar Mutu Sekolah Islam Terpadunya menyebutkan dan menambahkan bentukbentuk kegiatan kesiswaan yang dapat

\footnotetext{
${ }^{28}$ Sulistyowati, 134.

${ }_{29}$ Permendiknas No.39 tahun 2008
}

dikembangkan adalah sebagai berikut :

a. Pola perilaku hidup sehat secara Islami

b. Pola hidup gemar ibadah dan bangga berislam

c. Kepemimpinan dan karakter bangsa

d. Ketrampilan sosial

e. Kewirausahaan

f. Minat dan bakat ${ }^{30}$

\section{Prosedur Penilaian Pengembangan Nilai Karakter di Sekolah}

Dalam rangka mengetahui keberhasilan pelaksanaan pendidikan budaya dan karakter bangsa di sekolah diperlukan penilaian dengan menyusun indikator sebagai suatu tolok ukur. Adapun jenis indikator yang dikembangkan ada dua yaitu indikator untuk sekolah dan kelas yang kedua indikator untuk mata pelajaran yang difokuskan pada pembentukan nilai siswa sebagai individu.

a. Prosedur penilaian pada tingkat mata pelajaran. Penilaian terlaksananya penanaman karakter pada diri peserta didik di setiap mata pelajaran dapat dilakukan dengan menentukan indikator karakteryang ingin dibentuk dalam setiap mata pelajaran. Kemudian dilakukan cara penilaiannya. Yang tepat dalam hal ini adalah dengan teknik pengamatan, unjuk kerja, penugasan individual dan kelompok dan penilaian antar teman.

b. Prosedur penilaian pada satuan tingkat pendidikan. Penilaian terhadap pelaksanaan dan internalisasi nilai-nilai karakter dalam diri peserta didik dapat dilakukan pada tingkat satuan tingkat pendidikan. Tentunya hal ini ditentukan oleh pemangku kebijakan satuan pendidikan tersebut yang diturunkan dari visi dan misinya.

Pemantauan pembiasaan karakter oleh peserta didik dan pendidik dalam kehidupan akademik di sekolah merupakan

${ }^{30}$ Tim Penjamin Mutu JSIT Indonesia, Standar Mutu Kehasan SIT, 2014, 178-83. 
salah satu bentuk penilaian di tingkat satuan pendidikan. Dengan memperhatikan perubahan karakter pada umumnya pemangku kebijakansudah dapatmengambil analisis untuk diputuskan terlaksana tidaknya pembentukan karakter tersebut dalam diri pendidik dan peserta didik.

\section{E. Guru adalah Kunci Utama Kemajuan Bangsa}

Anies Baswedan dalam sambutannya di buku Gurunya Manusia menyebutkan bahwa pendidikan tidak dapat dilepaskan dari guru. Guru adalah ujung tombak proses pendidikan. Tidak mungkin bangsa Indonesia bisa membuat konversi tingkat melek hurufnya dari 5\% menjadi 92\%. Tanpa guru, tidak mungkin program pendirian sekolah dan universitas dapat berhasil. Tanpa guru tidak mungkin akan terwujud generasi berkualitas. ${ }^{31}$

Pendidikan berkualitas akan terwujud jika pelaku pendidikannya berkualitas. Guru yang berkualias adalah kuncinya. Mestinya guru menguasai dua konsep dasar, yaitu pengajaran (pedagogi) dan kepemimpinan (leadership). Guru harus kreatif dan selalu mengupdate mind setnya setiap saat karena setiap saat ada perubahan, demikian pula situasi dan kondisi yang berbeda tentunya menuntut seorang guru untuk lebih kreatif dan inovatif.

Guru harus mengembangkan dirinya secara mandiri (fardiyah) bukan karena hanya tuntutan, desakan dari pihak-pihak luar semisal pemerintah, sekolahnya dimana ia mengajar tetapi mengembangkan diri adalah kebutuhan mendasar seorang guru. Belajar mandiri adalah perwujudan dari harkat dan martabat seorang guru yang tinggi di tengah masyarakat. Guru harus menjadi dirinya sendiri untuk mengabdi pada pendidikan negeri ini. ${ }^{32}$

${ }^{31}$ Chatif, Sekolahnya Manusia, 16.

32 Doni Koesuma A, Pendidikan Karakter: Di Zaman Keblinger (Jakarta: Grasindo, 2010), 58.
Pola Teaching Centered Learning harus mulai digeser dengan pola Student Centered Learning. Guru harus mampu mengelola bukan menguasai kelas dengan baik. Guru adalah dirigent atau komponis yang mendisain panggung kelasnya dengan sebaik-baiknya sesuai dengan tipe kecerdasan peserta didik. Dalam hal ini seorang guru harus selalu belajar dan belajar untuk meningkatkan kapasitas dirinya. Bisa jadi siswa lebih cerdas dari guru karena sumber pembelajaran mudah didapatkan di mana saja dan kapan saja.

Selainituperanstakeholderjugasangat menentukan kinerja guru. Yang pertama kali dijadikan orientasi pembangunan di Jepang adalah memikirkan gurunya, maka guru harus menjadi prioritas utama. Namun, seorang guru tentu juga tidak semata mengejar duniawi saja tetapi menjadi guru adalah panggilan jiwa sehingga rasa ikhlas mendidik generasi masa depan itu menjadi prioritas utama dan menjadi tabungan amal sholih/amal jariyah yang akan dipetik kelak di akhirat.

\section{Kesimpulan}

Fase-fase perkembangan manusia pada umumnya memiliki fungsi, peran perkembangan yang berbeda-beda. Sejak awal anak-anak sampai dewasa memiliki peran fungsi dan peran yang berbedabeda. Di sinilah seorang pendidik harus mengetahuinya sebagai bekal memberikan treatment dan solusi bagi pembelajaran yang dilakukan. Masa-masa perkembangan adalah masa-masa penanaman nilai-nilai karakter bangsa yang sudah mulai dan lama luntur dari kepribadian bangsa Indonesia. Pendidikan karakter dilaksanakan dengan cara menginkludkan dalam setiap sesi pembelajaran baik kegiatan kesiswaan yang intrakurikuler maupun dalam kegiatan ekstrakurikulernya. Pendekatannya pun harus menyenangkan karena bukan aspek kognitif yang menjadi sasarannya tetapi 
aspek sikap dan praktek lapangannya yang dituntut. Akhirnya, semuanya ada di tangan guru, karena guru adalah pengelola utama kelas. Dan guru yang bisa mengelola kelas dengan baik adalah guru yang update, kreatif, inovatif dan mampu menjadi suri tauladan yang baik.

\section{Daftar Pustaka}

A, Doni Koesuma. Pendidikan Karakter: Di Zaman Keblinger. Jakarta: Grasindo, 2010.

- - - Pendidikan Karakter: Strategi Mendidik Anak di Zaman Global. Jakarta: Grasindo, 2007.

Akla. “Desain Pembelajaran Bahasa Arab berbasis Penanaman Karakter untuk Anak Usia Dini." Elementary: Jurnal Ilmiah Pendidikan Dasar 3, no. 2 (2017).

AM, Juhri. Landasan Wawasan Pendidikan: Suatu Pendekatan Kompetensi Guru. Cet. 4. Metro: Lembaga Penelitian UM Metro, 2013.

Arista Rosady F. Aning Tias. Hubungan antara Lingkungan Pergaulan dengan Sikap dan Perilaku Seks Bebas Remaja di SMK Murni 2 Surakarta. Surakata: Universitas Muhammadiyah Surakarta, 2015.

Chatif, Munif. Sekolahnya Manusia. II. Jakarta: Kaifa, 2012.

Departemen Pendidikan Nasional RI. UU RI No. 20 tahun 2003 tentang Sistem Pendidikan Nasional (Sisdiknas). Jakarta: Sinar Grafika, 2003.

Husaini, Adian. Pendidikan islam: Membentuk Manusia Berkarakter dan Beradab. Jakarta: Cakrawala Publishing, 2008.

Judiani, Sri. "Implementasi Pendidikan Karakter di Sekolah Dasar Melalui Penguatan Pelaksanaan Kurikulum." Jurnal Pendidikan dan Kebudayaan 16, no. III (Oktober 2010).

Karim, Hamdi A. "Pendidikan Karakter di Madrasah Ibtidaiyah." Elementary: Jurnal Ilmiah Pendidikan Dasar 2, no. 2 (2016).

Khotijah. "Strategi Pengembangan Bahasa pada Anak Usia Dini." Elementary: Jurnal Ilmiah Pendidikan Dasar 2, no. 2 (2016).

Madkur, Ahmad. "ELT in Indonesian Context: Which One is Better? NESTs or NNESTs." Iqra': Jurnal Kajian Ilmu Pendidikan 2, no. 2 (2017).

Mampuniarti,. "Perspektif Humanis Religius dalam Perspektif Inklusif,." Jurnal Pendidikan Khusus III, no. 2 (November 2010).

Mighwar, Muhammad Al. Psikologi Remaja: Petunjuk bagi Guru dan Orang Tua. Bandung: Pustaka Setia, 2006.

Moleong, Lexy J. Metode Penelitian Kualitatif. Bandung: Remaja Rosdakarya, 1990.

Mudiyaharjo, Redja. Pengantar Pendidikan: Sebuah Studi Awal Tentang Dasardasar Penddidikan pada Umumnya dan Pendididkan di Indonesia. Jakarta: PT Raja Grafindo Persada, 2002.

Mujib, Abdul dan Madkur, Ahmad. "Islamicbased Life Skill Education on State VocationalHighSchoolin Metro City." dipresentasikan pada Proceeding the First International Conference on Law, Economics and Education, Universitas Muhammadiyah Metro, 2016.

Ramadhani, Fadhilah, dan Duta Nurdibyanandaru. "Pengaruh SelfCompassion terhadap Kompetensi Emosi Remaja Akhir." Jurnal Psikologi Klinis dan Kesehatan Mental 3, no. 3 (2014).

Ramayulis. Ilmu Pendidikan Islam. Jakarta: Kalam Mulia, 2004. 
62| Hlementiarly Vol. 4 Edisi Januari-Juni 2018

Sulistyowati, Endah. Implementasi Kurikulum Pendidikan Karakter. Yogyakarta: PT. Cintra Aji Parama, 2012.

Tim Penjamin Mutu JSIT Indonesia. Standar Mutu Kehasan SIT, 2014.

Zakiah Daradjat, dkk. Ilmu Pendidikan Islam. Jakarta: Bumi Aksara, 1992.

Zubaedi. Desain Pendidikan Karakter: Konsepsi dan Aplikasinya dalam Lembaga Pendidikan. Jakarta: Kencana, 2011. 